\title{
A review of the Ompok hypophthalmus group of silurid catfishes with the description of a new species from South-East Asia
}

\author{
H. H. $\mathrm{NG}_{\mathrm{G}}$ \\ Fish Division, Museum of Zoology, University of Michigan, 1109 Geddes Avenue, Ann \\ Arbor, MI 48109-1079, U.S.A.
}

(Received 29 August 2001, Accepted 28 March 2003)

\begin{abstract}
The identities of the nominal species in the Ompok hypophthalmus group of silurid catfishes, namely Ompok hypophthalmus, O. macronema and O. urbaini are verified in this study. Ompok macronema is hypothesized to be a junior synonym of $O$. hypophthalmus, and $O$. urbaini (previously considered a junior synonym of $O$. hypophthalmus) is hypothesized to be valid, distinct species. Ompok hypophthalmus is restricted to Java and the Barito River drainage in southern Borneo, and the material previously identified as O. hypophthalmus from Sumatra, the Malay Peninsula and Borneo represents $O$. rhadinurus, a new species.

(C) 2003 The Fisheries Society of the British Isles
\end{abstract}

Key words: catfish; new species; Ompok; Siluridae; South-East Asia.

\section{INTRODUCTION}

Catfishes of the genus Ompok La Cepede, are medium-sized members of the Siluridae usually found in lakes and large rivers throughout South and SouthEast Asia. The genus has been demonstrated to be paraphyletic by Bornbusch (1995), who recognized four distinct clades within Ompok, namely the O. bimaculatus (Bloch) group, O. leiacanthus (Bleeker) group, O. hypophthalmus group (Bleeker) and the O. eugeneiatus (Vaillant) group. The O. hypophthalmus group is diagnosed by each of the cartilaginous plates supporting the mandibular barbels having two posterior processes ( $v$. plates poorly developed or with a single dorsolateral process or elongate and hourglass-shaped and without processes).

A detailed examination of $O$. hypophthalmus from throughout its range reveals that there are distinct differences among the populations from Java, Indo-China and the rest of Sundaic South-East Asia (Borneo, Sumatra and the Malay Peninsula). These differences are considered distinct enough to warrant recognition of the three populations as belonging to distinct species. Therefore, the material from Java is assigned to O. hypophthalmus, those from Indo-China assigned to $O$. urbaini (Fang \& Chaux) and those from the rest of Sundaic

Tel.: +1 734647 2192; fax: +1 734763 4080; email: heokheen@umich.edu 
South-East Asia assigned to a third species, which is described here as $O$. rhadinurus, a new species. The purpose of this study is to rediagnose and redescribe all three species of Ompok belonging to the O. hypophthalmus group.

\section{MATERIALS AND METHODS}

Measurements were made with a dial calliper and data recorded to $0 \cdot 1 \mathrm{~mm}$. Counts and measurements were made on the left side of the specimens when possible. In tables and text, subunits of the head are presented as proportions of head length $\left(L_{\mathrm{H}}\right)$. Head length and measurements of body parts are given as proportions of standard length $\left(L_{\mathrm{S}}\right)$.

The measurements and terminologies follow largely those of Bornbusch (1991), with the following exceptions: length of the dorsal base includes the base of the first and last dorsal-fin ray and the distance between them. Pelvic-fin length is measured from the base to the tip of the longest ray. Caudal-fin length is the length of the longest ray of the upper lobe measured from the posterior margin of the hypural complex. Body depth at the anus is measured as the vertical distance from the midline of the dorsal surface to the midline of the ventral surface at the anus. Head width is measured across its widest point (at a point immediately anterior to the base of pectoral spine) but discounting any lateral projection of the branchiostegal membranes. Head depth is measured at the base of the occipital process. Interorbital length is the shortest distance across the bony interorbit.

Drawings of the specimens were made with a Wild M5 microscopic camera lucida. Institutional acronyms follow Eschmeyer (1998).

\section{RESULTS}

OMPOK HYPOPHTHALMUS (BLEEKER, 1846) [FIGS 1 AND 5(A)]

Silurus hypophthalmus Bleeker, $1846 a$ : 149 (type locality: Batavia); 1855b: 395, 396.

Silurus hijpophthalmus Bleeker, 1846b: 284.

Silurus macronema Bleeker, 1851a: 203 (type locality: Bandjermassing); 1851b: 420; 1852: 412; 1853: 432; 1854: 65; 1855a: 156.

Silurodes hypophthalmus Bleeker, 1858: 272 (in part); 1862: 83, P1. 87 Fig. 2 (in part); Weber \& de Beaufort, 1913: 205 (in part).

Silurodes macronema Bleeker, 1857: 8; 1860a: 19.

Callichrous hypophthalmus Günther, 1864: 48 (in part).

Callichrous macronema Günther, 1864: 49.

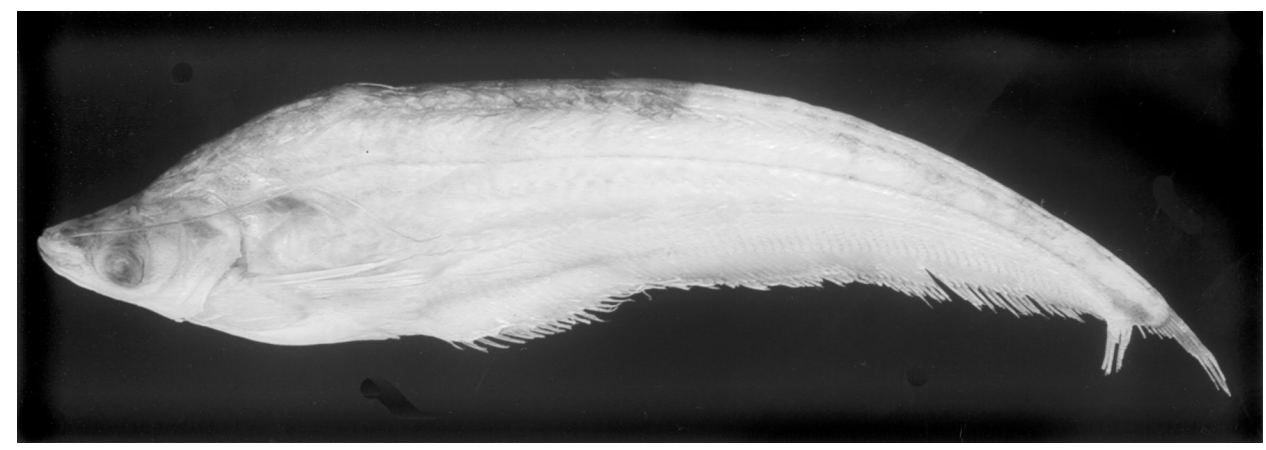

FIG. 1. Ompok hypophthalmus, ZRC 40036, 175.3 mm Ls; Borneo: Banjarmasin. 
Ompok hypophthalmus Haig, 1952: 105 (in part); Kottelat et al., 1993: 70 (in part); Roberts, 1993a: 32.

\section{Material examined}

UMMZ 155798, 6 ex., 126.0-130.8 $\mathrm{mm} L_{\mathrm{S}}$; Java: vicinity of Batavia. ZMA 120.543, 257.2 mm $L_{S}$; Java: East Java, Surabaya. CMK 11856, 1 ex., 137.8 mm $L_{S}$; Borneo: Kalimantan Tengah, market in Puruk Cahu. ZRC 40036, 1 ex., $175.3 \mathrm{~mm} L_{\mathrm{S}}$; Borneo: Kalimantan Selatan, Banjarmasin, Pasar Kuin.

\section{Diagnosis}

A species of Ompok with a combination of the following characters: head width $10 \cdot 0-10 \cdot 7 \% L_{\mathrm{S}}$, depth of caudal peduncle $4 \cdot 3-5 \cdot 1 \% L_{\mathrm{S}}, 74-80$ anal-fin rays, and $54-55$ vertebrae.

\section{Description}

Body and head laterally compressed. Dorsal profile somewhat humped with a distinct nuchal concavity, descending gently from dorsal-fin origin to snout tip, and again from the posteriormost dorsal-fin ray to the caudal peduncle. Anterior profile of snout rounded. Anterior pair of nostrils tubular and anteromedial to maxillary barbel base. Posterior pair of nostrils bordered by fleshy dorsal and ventral membranes and posteromedial to maxillary barbel base.

Mouth terminal; gape oblique. Rictal lobes narrowly continuous at rictus and deeply subtended by submandibular groove, with upper rictal lobe lacking skin fold.

Teeth villiform. Dentary teeth in slightly curved, elongate bands narrowing posteriorly, reaching from symphysis almost to mouth corners; premaxillary teeth in broader, slightly curved rectangular bands. Vomerine teeth in a single crescentic band.

Maxillary barbels slightly flattened for entire length, reaching to anterior third of anal fin. Single pair of mandibular barbels present; located slightly anterolateral to gular fold; barbels flattened for most of length, reaching to vertical through anterior orbital margin.

Eyes small, subcutaneous; located in middle of head; visible dorsally and more so ventrally.

Gill membranes separate and overlapping, free from isthmus. Branchiostegal rays 10 (2) or 11 (4). Gill rakers short, anteriormost rakers on lower first arch small and widely spaced; 3 on epibranchial and 11-13 on ceratobranchial.

Distal margin of pectoral fin broadly convex, with I,11 (1), I,12 (1), I,13 (2) or I,14 (2) rays. Proximal two-thirds of first pectoral-fin element co-ossified into a spine without anterior serrations. Pectoral spine with 2-4 distinct posterior serrations, increasing in size distally; proximal articulated segments with 2-5 smaller posterior serrations; distalmost segments lack dentition.

Distal margin of pelvic-fin convex, with i,5,i (6) rays. Distal margin of dorsal fin pointed, with i,2,i (4) or i,3 (2) rays; segments of first ray not co-ossified to form spine. Distal margin of anal fin straight, with 74 (1), 77 (1), 78 (1), 79 (1) or 80 (2) rays; separate from caudal fin. Integument over anal fin thickened proximally for slightly more than half of ray lengths; fin-ray erector muscles extending along anterior edges of anal-fin rays, ventralmost extent of muscles that of thickened integument. Caudal fin strongly forked; principal rays i,7,7,i 
(2), i,7,8,i (2), i,8,7,i (1) or i,8,8,i (1). Urogenital papillae of both sexes located immediately posterior to insertions of pelvic fins.

In $\% L_{\mathrm{S}}: L_{\mathrm{H}} 18 \cdot 1-19 \cdot 6$, head width $10 \cdot 0-10 \cdot 7$, head depth $10 \cdot 1-10 \cdot 7$, predorsal distance $28 \cdot 1-31 \cdot 2$, preanal length $33 \cdot 4-36 \cdot 1$, prepelvic length $31 \cdot 0-31 \cdot 6$, prepectoral length 19.4-20.6, body depth at anus 18.9-21.9, depth of caudal peduncle $4 \cdot 3-5 \cdot 1$, pectoral-spine length $10 \cdot 6-12 \cdot 4$, pectoral-fin length $18 \cdot 1-19 \cdot 1$, length of dorsal-fin 9.5-12.6, pelvic-fin length 5.1-6.4, length of anal-fin base 60.4-66.1, caudal-fin length 17.7-19.5; in \% $L_{\mathrm{H}}$ : snout length $42 \cdot 1-44 \cdot 7$, interorbital distance $46 \cdot 8-51 \cdot 9$, eye diameter $16 \cdot 9-21 \cdot 1$, maxillary barbel length 262.8-341.4, mandibular barbel length $27 \cdot 8-43 \cdot 0$. Vertebrae $11+43=54$ (1), $12+42=54(1)$ or $12+43=55(5)$.

\section{Colour}

Dorsal surface and sides of head pale brown, fading to a lighter colour on flanks and thickened integument over anal fin. Lateral line with a thin black stripe. Another faint black midlateral line below lateral line variably present, usually as series of scattered melanophores broadening both at humeral region and base of caudal peduncle to form dark roughly elliptical spots. Maxillary and mandibular barbels pale brown, gradually fading in colour distally. Anal fin with hyaline ventral margin. All other fins hyaline, with small dark-brown spots present in some specimens.

\section{Distribution}

Known from the Ciliwung and Brantas river drainages in Java and the Barito River drainage in southern Borneo (Fig. 2).

\section{Biology}

The biology of $O$. hypophthalmus is unknown, but is most probably similar to $O$. rhadinurus and $O$. urbaini.

\section{OMPOK RHADINURUS NEW SPECIES [FIGS 3 AND 5(b)]}

Silurus hijpophthalmus (non Bleeker) Bleeker, 1854: 65.

Silurodes hypophthalmus (non Bleeker) Bleeker (1858): 272 (in part); 1858-59: 263, 264; 1860b: 6, 47; 1862: 83, Pl. 87 Fig. 2 (in part); Weber \& de Beaufort, 1912: 534; 1913: 205 (in part); Smith, 1933: 77 (in part); 1945: 336; Hardenberg, 1936: 232; Suvatti, 1936: 72 (in part); 1950: 291 (in part); 1981: 87 (in part); Imaki et al., 1981: 40; Mizuno \& Furtado, 1982: 324, Pl. 4C Fig. 4.

Callichrous hypophthalmus (non Bleeker) Günther, 1864: 48 (in part); Volz, 1904: 465; 1907: 163.

Callichrous pabda (non Hamilton) Duncker, 1904: 172.

Ompok hypophthalmus (non Bleeker) Haig, 1952: 105 (in part); Roberts, 1989: 150; Kottelat et al., 1992: 10; Ng et al., 1992: 21; Kottelat et al., 1993: 70, P1. 34 (in part); Lim et al., 1993: 7; Khan et al., 1996: 39; Lim et al. (1999): 383; Ng \& Tan, 1999: 357; Tan \& Ng, 2000: 285.

Ompok bimaculatus (non Bloch) Mohsin et al., 1977: 76; Mohsin \& Ambak, 1983: 140, Fig. 106.

Ompok pabda (non Hamilton) Mohsin \& Ambak, 1982: 110. 


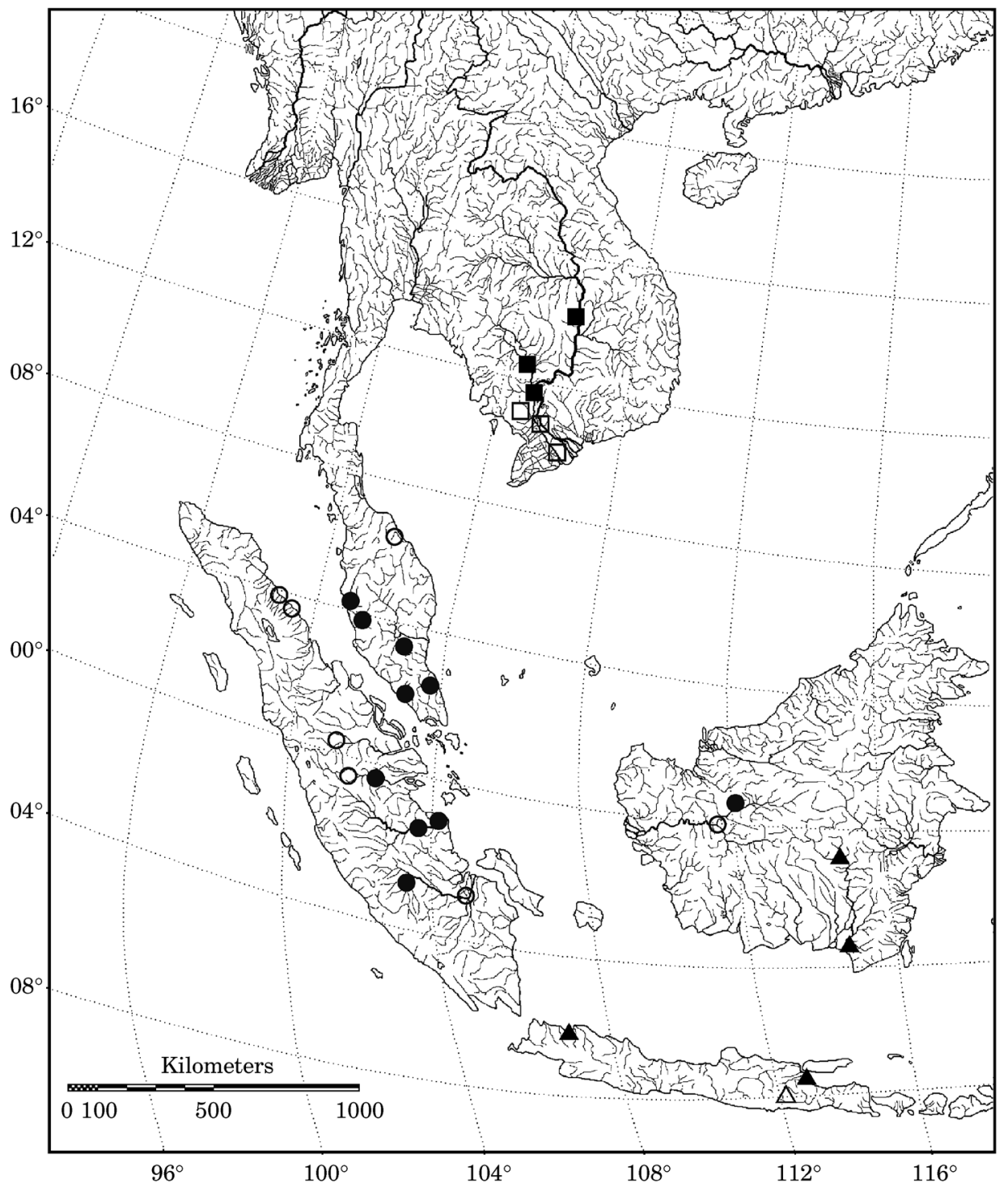

Fig. 2. Map of South-East Asia showing distributions (according to collection localities) of: Ompok hypophthalmus $(\Delta \triangle)$, O. rhadinurus $(\bullet \circ)$ and $O$. urbaini $(\square)$. Closed symbols denote records based on material examined. Open symbols denote published records.

\section{Holotype}

ZRC 14897, 190.8 mm $L_{\mathrm{S}}$; Peninsular Malaysia: Selangor, North Selangor Peat Swamp Forest, irrigation canal on western boundary, NUS 1991-92 Zoology Honours Class, 20 June 1991.

\section{Paratypes}

Sumatra: CMK 4726, 3 ex., $127.0-168.0 \mathrm{~mm} \quad L_{\mathrm{S}}$; market in Jambi; P.G. Bianco \& M. Kottelat, 9 December 1984. UMMZ 155678, 1 ex., 


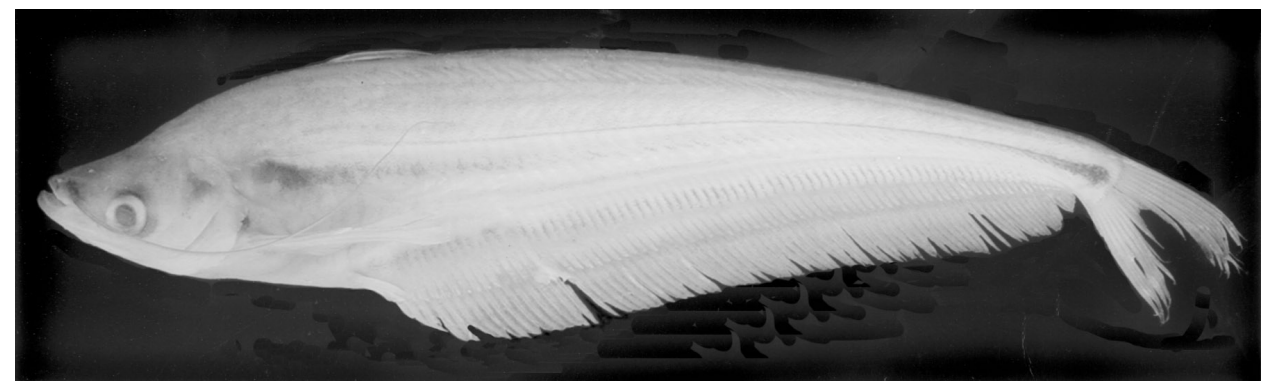

FIG. 3. Ompok rhadinurus, ZRC 41718, paratype, $167.4 \mathrm{~mm} L_{\mathrm{S}}$; Sumatra: Danau Arang Arang.

151.7 mm $L_{\mathrm{S}}$; UMMZ 155679, 2 ex., 80.9-94.2 mm $L_{\mathrm{S}}$; Musi River, Moeara [=Muara] Klingi; A. Thienemann, date unknown. CMK 11222, 2 ex., 139.0-141.0 mm $L_{\mathrm{S}}$; ZRC 38665, 2 ex., 124.0-157.8 $\mathrm{mm} L_{\mathrm{S}}$; Jambi, Batang Hari near Tanjung Johor, a few km downstream of Jambi; M. Kottelat \& H.H. Tan, 5 June 1994. ZRC 38990, 8 ex., 149.2-186.1 mm $L_{S}$; Jambi, Pasar Angso Duo; P.K.L. Ng et al., June 1995. ZRC 39006, 4 ex., 140.2-167.8 mm $L_{\text {S }}$; Riau, blackwater stream from degraded peat swamp, $6 \mathrm{~km}$ to Rengat on JambiRengat Road; P.K.L. Ng et al., 13 June 1995. ZRC 39033, 3 ex., 134.4-182.4 mm $L_{S}$; Riau, Sungai Bengkwan, tributary of the Indragiri (Batang Kuantan), $4 \mathrm{~h}$ downstream of Rengat; P.K.L. Ng et al., 14 June 1995. ZRC 39149, 1 ex., 158.1 mm $L_{S}$; Jambi, Berbak Nature Reserve, Sungai Air Hitam Dalam; H.H. Ng \& S.H. Tan, 16-17 June 1995. ZRC 41718, 2 ex., 166.3-179.6 mm $L_{\mathrm{S}}$; Jambi, Danau Arang Arang, brownwater lake $\left(1^{\circ} 37^{\prime} 32 \cdot 0^{\prime \prime} \mathrm{S}\right.$; 1034' 19.0' E); H.H. Tan \& H.H. Ng, 25 July 1997.

Peninsular Malaysia: ZRC 14898, 1 ex., 193.1 $\mathrm{mm} L_{\mathrm{S}}$; data as for holotype. ZRC 15073, 1 ex., 182.5 mm $L_{S}$; Selangor, North Selangor Peat Swamp Forest, irrigation canal at Bernam headwaters, NUS 1991-92 Zoology Honours Class, 19 June 1991. ZRC 15074, 1 ex., 103.5 mm $L_{S}$; Selangor, North Selangor Peat Swamp Forest, irrigation canal on western boundary, NUS 1991-92 Zoology Honours Class, 18 June 1991. ZRC 23293, 1 ex., 139.3 mm $L_{\mathrm{S}}$; Johor, MuarLabis road, Sungai Labis. ZRC 24581-24583, 3 ex., 169.2-173.0 mm $L_{\mathrm{S}}$; Selangor, Sabak Bernam; P.K.L. Ng, June 1992. ZRC 42755, 1 ex., 97.2 mm $L_{\mathrm{S}}$; Johor, Sungai Kahang; H.H. Tan et al., 1 April 1998.

Borneo: CMK 10126, 1 ex., 63.2 $\mathrm{mm} L_{S}$; Kalimantan Barat: Sungai Santik, a tributary of Sungai Tawang, immediately West of Danau Sentarum Field Centre; M. Kottelat et al., 4 September 1993. CMK 10233, 1 ex., 73.2 mm $L_{\mathrm{S}}$; Kalimantan Barat: Nanga Semunak (dry season location); $0^{\circ} 56^{\prime} 37^{\prime \prime} \mathrm{N}$; $112^{\circ} 05^{\prime} 31^{\prime \prime} \mathrm{E}$; M. Kottelat et al., 8 September 1993. CMK 10351, 1 ex., $193.0 \mathrm{~mm} L_{\mathrm{S}}$; Kalimantan Barat: Sungai Tawang near Nanga Kenelang; from fishermen; M. Kottelat et al., 10 September 1993. CMK 10364, 2 ex., 138.0-151.0 mm $L_{S}$; Kalimantan Barat: Sungai Tengkidap in Nanga Sumbuk; $0^{\circ} 42^{\prime} 15^{\prime \prime} \mathrm{N} ; 112^{\circ} 06^{\prime} 26^{\prime \prime} \mathrm{E}$; M. Kottelat et al., 11 September 1993. CMK 10411, 1, $133 \mathrm{~mm} L_{\mathrm{S}}$; Kalimantan Barat: Sungai Tawang at Teluk Benanga, upriver of Nanga Pengembung; castnet; $0^{\circ} 49^{\prime} 15^{\prime \prime} \mathrm{N}$; $112^{\circ} 02^{\prime} 39^{\prime \prime} \mathrm{E}$; M. Kottelat et al., 11 September 1993. CMK 10466, 1 ex., 155.0 mm $L_{S}$; Kalimantan Barat: Sungai Kapuas at Nanga Al-Fazal, southern shore; $0^{\circ} 37^{\prime} 35^{\prime \prime} \mathrm{N} ; 112^{\circ} 03^{\prime} 58^{\prime \prime} \mathrm{E}$; 
M. Kottelat et al., 12 September 1993. CMK 11636, 1 ex., $132.0 \mathrm{~mm} L_{\mathrm{S}}$; Kalimantan Barat: Sungai Embau between Kampung Kelampai and Kampung Temenang (first rapids); M. Kottelat et al., 9 June 1995. CMK 11658, 1 ex., $84.2 \mathrm{~mm} L_{\mathrm{S}}$; Kalimantan Barat: Danau Batuk, lake adjacent to Kapuas immediately downriver of Jongkong; $0^{\circ} 40^{\prime} 37^{\prime \prime} \mathrm{N} ; 112^{\circ} 16^{\prime} 13^{\prime \prime} \mathrm{E}$; M. Kottelat et al., 10 June 1995.

\section{Non-types}

ZRC 2987, 1 ex., 172.2 mm $L_{S}$; Peninsular Malaysia: Pahang, Tasek Chini; L.F. de Beaufort, 20 July 1927. ZRC 2988, 1 ex., $188.3 \mathrm{~mm} L_{\mathrm{S}}$; Peninsular Malaysia: Perak, Telok Anson; L.F. de Beaufort, 10 December 1922. ZRC 8062, 1 ex., 214.4 mm $L_{S}$; Peninsular Malaysia: Pahang, Tasek Bera; J.I. Furtado, 11 December 1967. ZRC 8149-8150, 2 ex., 193.3-196.0 mm $L_{\mathrm{S}}$; Peninsular Malaysia: Pahang, Tasek Chini; J. Hutton, 18 April 1966. ZRC 12156-12158, 3 ex., 158.4-202.6 mm $L_{S}$; Peninsular Malaysia: Pahang, Tasek Bera; J.I. Furtado, 9 October 1968. ZRC 41520, 2 ex., 169.0-194.7 mm $L_{S}$; Sumatra: Jambi, Angso Duo fishmarket; H.H. Tan \& H.H. Ng, 23-29 July 1997. ZRC 42264, 6 ex., 108.9-196.0 mm $L_{S}$; Jambi, from fishermen at coffeeshop c. 15 min after Kampung Rantau Panjang along Batang Hari confluence; H.H. Tan et al., 6 June 1996. ZRC 42339, 1 ex., 68.6 mm $L_{S}$; Sumatra: Jambi, Pijoan, Danau Saut Padang; H.H. Tan et al., 8 June 1996.

\section{Diagnosis}

A species of Ompok with a combination of the following characters: head width $11 \cdot 4-13 \cdot 3 \% L_{\mathrm{S}}$, depth of caudal peduncle $3 \cdot 7-4.3 \% L_{\mathrm{S}}, 76-85$ anal-fin rays, and $56-58$ vertebrae.

\section{Description}

Body laterally compressed. Head somewhat depressed. Dorsal profile straight, descending gently from dorsal-fin origin to snout tip. Anterior profile of snout rounded. Anterior pair of nostrils tubular and anteromedial to maxillary barbel base. Posterior pair of nostrils bordered by fleshy dorsal and ventral membranes and posteromedial to maxillary barbel base.

Mouth subterminal; gape horizontal or very slightly oblique. Rictal lobes narrowly continuous at rictus and deeply subtended by submandibular groove, with upper rictal lobe lacking skin fold.

Teeth villiform. Dentary teeth in slightly curved, elongate bands narrowing posteriorly, reaching from symphysis almost to mouth corners; premaxillary teeth in broader, slightly curved rectangular bands. Vomerine teeth in a single ovoid patch.

Maxillary barbels slightly flattened for entire length, reaching to anterior third of anal fin. Single pair of mandibular barbels present; located slightly anterolateral to gular fold; barbels flattened for most of length, reaching to vertical just beyond posterior orbital margin.

Eyes small, subcutaneous; located in anterior half of head; visible both dorsally and ventrally.

Gill membranes separate and overlapping, free from isthmus. Branchiostegal rays 11 (13) or 12 (1). Gill rakers short, anteriormost rakers on lower first arch small and widely spaced; 3-4 on epibranchial and 11-13 on ceratobranchial. 
Distal margin of pectoral fin broadly convex, with I,12 (8), I,13 (3) or I,14 (3) rays. Proximal two-thirds of first pectoral-fin element co-ossified into a spine without anterior serrations. Pectoral spine with 2-6 distinct posterior serrations, increasing in size distally; proximal articulated segments with 2-6 smaller posterior serrations; distalmost segments lack dentition.

Distal margin of pelvic-fin convex, with i,7 (14) rays. Distal margin of dorsal fin pointed, with i,2 (2), i,2,i (3) or i,3 (9) rays; segments of first ray not co-ossified to form spine. Distal margin of anal fin straight, with 76 (1), 77 (1), 79 (6), 78 (1), 80 (2), 81 (2), 82 (1) or 85 (1) rays; separate from caudal fin. Integument over anal fin thickened proximally for slightly more than half of ray lengths; fin-ray erector muscles extending along anterior edges of anal-fin rays, ventralmost extent of muscles that of thickened integument. Caudal fin obliquely truncate or emarginate, upper lobe equal to or longer than lower lobe; principal rays $\mathrm{i}, 7,7, \mathrm{i}(3), \mathrm{i}, 7,8, \mathrm{i}(10)$ or $\mathrm{i}, 8,7, \mathrm{i}(1)$. Urogenital papillae of both sexes located immediately posterior to insertions of pelvic fins. In $\% L_{\mathrm{S}}: L_{\mathrm{H}}$ 18.2-20.6, head width 11.4-13.3, head depth 10.7-12.1, predorsal distance 28.9-31.5, preanal length $31 \cdot 7-36 \cdot 3$, prepelvic length $28 \cdot 2-31 \cdot 7$, prepectoral length $19 \cdot 2-21 \cdot 4$, body depth at anus $21 \cdot 2-24 \cdot 5$, depth of caudal peduncle $3 \cdot 7-4 \cdot 3$, pectoral-spine length $10 \cdot 5-14 \cdot 0$, pectoral-fin length $18 \cdot 4-20 \cdot 3$, length of dorsalfin $9 \cdot 5-11 \cdot 7$, pelvic-fin length $5 \cdot 0-5 \cdot 9$, length of anal-fin base $61 \cdot 3-66 \cdot 6$, caudalfin length 16.2-17.6; in $\% L_{\mathrm{H}}$ : snout length $39 \cdot 4-47 \cdot 5$, interorbital distance 53.1-61.2, eye diameter 16.6-21.6, maxillary barbel length 289.7-351.6, mandibular barbel length 19.1-41.7. Vertebrae $12+44=56$ (2), $11+46=57$ (1), $12+45=57(8), 13+44=57(1), 12+46=58(1)$ or $13+45=58(1)$.

\section{Colour}

Dorsal surface and sides of head pale brown, fading to a lighter colour on flanks and thickened integument over anal fin. Lateral line with a thin black stripe. Another faint black midlateral line below lateral line variably present, usually as series of scattered melanophores broadening both at humeral region and base of caudal peduncle to form dark roughly elliptical spots. Maxillary and mandibular barbels pale brown, gradually fading in colour distally. Anal fin with hyaline ventral margin. All other fins hyaline, with small dark-brown spots present in some specimens.

\section{Etymology}

From the Greek rhadinos, meaning tapering, and ouros, meaning tail. In reference to the slender caudal peduncle of this species.

\section{Distribution}

Known from the Kapuas River drainage in western Borneo, the Batang Hari, Deli, Indragiri and Musi River drainages in Sumatra, and the Bernam, Endau, Pahang, Pattani and Perak River drainages in the Malay Peninsula (Fig. 2).

\section{Biology}

Ompok rhadinurus is found in large, slow flowing rivers and lakes, although juveniles are sometimes found in smaller streams. It feeds on smaller fishes and crustaceans (Mizuno \& Furtado, 1982). 


\section{OMPOK URBAINI (FANG \& CHAUX, 1949) [FIG.4]}

Cryptopterus urbaini Chaux \& Fang, 1949: 197, Fig. 2 (type locality: Tonle Sap, Cambodia).

Silurodes hypophthalmus (non Bleeker) Smith, 1933: 77 (in part); 1945: 336; Suvatti, 1936: 72 (in part); 1950: 291 (in part); 1981: 87 (in part); Chevey \& le Poulain, 1940: 20; Durand, 1940: 18; Kuronuma, 1961: 5; Orsi, 1974: 162; Taki, 1978: 18.

Ompok hypophthalmus (non Bleeker) Haig, 1952: 105 (in part); Kottelat, 1985: 269; 2001: 128, Fig. 354; Roberts, 1993b: 34; Bornbusch, 1995: 43 (in part); Rainboth, 1996: 149, Pl. XX Fig. 156; Vidthayanon et al., 1998: 45; Lim et al., 1999: 383; Kavanantkul et al., 2000: 38; Kottelat, 2001: 128, Fig. 354.

Kryptopterus bicirrhis (non Bleeker) Kottelat, 1985: 268 (in part).

Siluroides hypophtalmus [sic.] (non Bleeker) Mai \& Nguyen, 1988: 49.

Siluroides [sic.] hypophthalmus (non Bleeker) Mai et al., 1992: 156; Hương \& Khoa, 1993: 158, Fig. 67 (figure caption misspelled Siluroides hymenopthalmus).

Ompok cf. hypophthalmus Roberts \& Warren, 1994: 102.

Kryptopterus cheveyi (non Durand) Serov, 1994a: 24 (in part); 1994b: 64 (in part).

Ompok urbaini Bornbusch, 1995: 44.

\section{Material examined}

MNHN 1966-706, 1 ex., syntype, $181.0 \mathrm{~mm} L_{\mathrm{S}}$; MNHN 1966-707, 1 ex., syntype, $165.0 \mathrm{~mm} L_{\mathrm{S}}$; MNHN 1966-708, 1 ex., syntype, 112.6 mm $L_{\mathrm{S}}$; Cambodia: Tonle Sap. UMMZ 232360, 1 ex., 92.2 $\mathrm{mm} L_{\mathrm{S}}$; Cambodia: Kompong Chhnang, Tonle Sap at Kompong Chhnang fishing lot 9 in second channel east of town. UMMZ 232378, 5 ex., 84.1-119.0 $\mathrm{mm} L_{\mathrm{S}}$; UMMZ 234411, 2 ex., 85.5-96.8 mm $L_{S}$; Cambodia: Kandal, Prek Ta Pov, $13 \mathrm{~km}$ south of Phnom Penh. UMMZ 232427, 4 ex., 90.0-107.7 mm $L_{S}$; Cambodia: Siem Reap, floating village at mouth of Siem Reap River. UMMZ 232737, 39 ex., 92.5-125.2 mm $L_{\mathrm{S}}$; Cambodia: Tonle Sap at exit to Great Lake, $4 \mathrm{~km}$ north-west of Chhnok Trou at Kompong Thom fishing lot 2. UMMZ 235389, 1 ex., $108.8 \mathrm{~mm} L_{\mathrm{S}}$; Laos: Champasak, Mekong River at Ban Hang Khone, just downstream from Khone Falls.

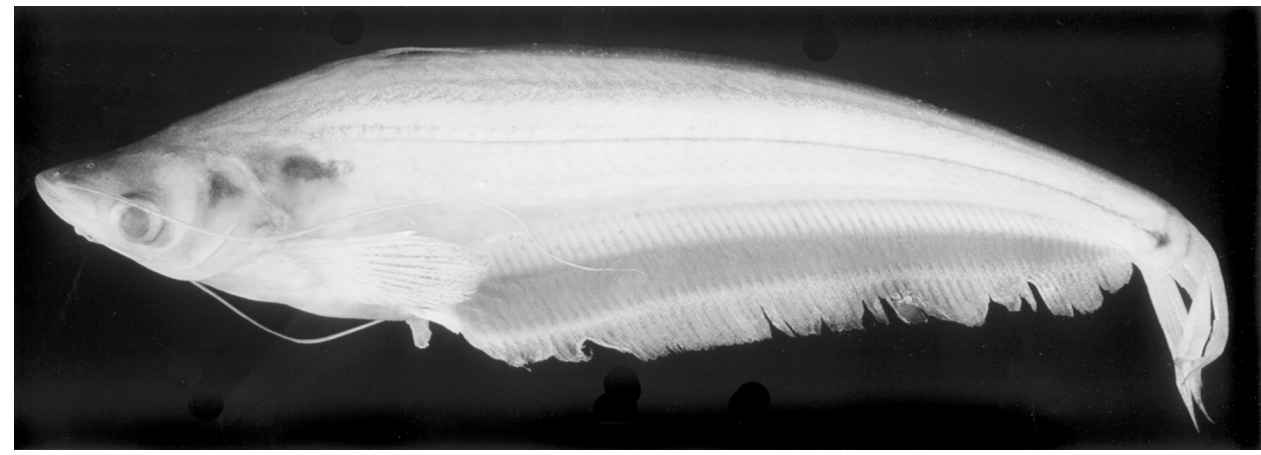

FIG. 4. Ompok urbaini, UMMZ 232737, 125.2 mm L S $_{\text {; }}$ Cambodia: Tonle Sap. 


\section{Diagnosis}

A species of Ompok with a combination of the following characters: head width $11.7-13.6 \% L_{\mathrm{S}}$, depth of caudal peduncle $5 \cdot 2-5.9 \% L_{\mathrm{S}}, 65-71$ anal-fin rays, and $47-52$ vertebrae.

\section{Description}

Body and head laterally compressed. Dorsal profile somewhat humped with a distinct nuchal concavity; descending gently from dorsal-fin origin to snout tip, and again from the posteriormost dorsal-fin ray to the caudal peduncle. Anterior profile of snout rounded. Anterior pair of nostrils tubular and anteromedial to maxillary barbel base. Posterior pair of nostrils bordered by fleshy dorsal and ventral membranes and posteromedial to maxillary barbel base.

Mouth terminal; gape oblique. Rictal lobes narrowly continuous at rictus and deeply subtended by submandibular groove, with upper rictal lobe lacking skin fold.

Teeth villiform. Dentary teeth in slightly curved, elongate bands narrowing posteriorly, reaching from symphysis almost to mouth corners; premaxillary teeth in broader, slightly curved rectangular bands. Vomerine teeth in a single crescentic band.

Maxillary barbels slightly flattened for entire length, reaching to anterior third of anal fin. Single pair of mandibular barbels present; located slightly anterolateral to gular fold; barbels flattened for most of length, reaching to vertical just beyond posterior orbital margin.

Eyes small, subcutaneous; located in middle of head; visible dorsally, and more so ventrally.

Gill membranes separate and overlapping, free from isthmus. Branchiostegal rays 11 (14). Gill rakers short, anteriormost rakers on lower first arch small and widely spaced; 3-4 on epibranchial and 12-13 on ceratobranchial.

Distal margin of pectoral fin broadly convex, with I,11 (5), I,12 (8) or I,12,i (1) rays. Proximal two-thirds of first pectoral-fin element co-ossified into a spine without anterior serrations. Pectoral spine with 2-7 distinct posterior serrations, increasing in size distally; proximal articulated segments with 2-4 smaller posterior serrations; distalmost segments lack dentition.

Distal margin of pelvic-fin convex, with i,7 (14) rays. Distal margin of dorsal fin pointed, with i,2,i (2) or i,3 (12) rays; segments of first ray not co-ossified to form spine. Distal margin of anal fin straight, with 65(4), 66 (3), 67 (3), 68 (2), 70 (1) or 71 (1) rays; separate from caudal fin. Integument over anal fin thickened proximally for slightly more than half of ray lengths; fin-ray erector muscles extending along anterior edges of anal-fin rays, ventralmost extent of muscles that of thickened integument. Caudal fin strongly forked; principal rays $\mathrm{i}, 7,7, \mathrm{i}$ (1) or i,7,8,i (13). Urogenital papillae of both sexes located immediately posterior to insertions of pelvic fins. In $\% L_{\mathrm{S}}: L_{\mathrm{H}} 20 \cdot 1-21 \cdot 3$, head width 11.7-13.6, head depth $10 \cdot 7-12 \cdot 4$, predorsal distance $30 \cdot 3-33 \cdot 8$, preanal length $35 \cdot 8-37 \cdot 4$, prepelvic length $32 \cdot 0-34 \cdot 1$, prepectoral length $20 \cdot 9-22 \cdot 7$, body depth at anus 21.1-24.2, depth of caudal peduncle 5.2-5.9, pectoral-spine length 10.7-13.1, pectoral-fin length $18 \cdot 5-21 \cdot 3$, length of dorsal-fin 13.9-15.0, pelvic-fin length $5 \cdot 1-6 \cdot 5$, length of anal-fin base $60 \cdot 8-65 \cdot 4$, caudal-fin length $16 \cdot 2-21 \cdot 3$; in $\% L_{\mathrm{H}}$ : snout length $42 \cdot 7-44 \cdot 0$, interorbital distance $49 \cdot 6-56 \cdot 2$, eye diameter 
20.0-25.2, maxillary barbel length 287.5-313.4, mandibular barbel length $45 \cdot 8-65 \cdot 2$. Vertebrae $12+35=47(1), 11+38=49(1), 11+39=50(1), 12+38=50$ (3), $11+40=51(1), 12+39=51(5)$ or $12+40=52(2)$.

\section{Colour}

Dorsal surface and sides of head pale brown, fading to a lighter colour on flanks and thickened integument over anal fin. Lateral line with a thin black stripe. Another faint black midlateral line below lateral line variably present, usually as series of scattered melanophores broadening both at humeral region and base of caudal peduncle to form dark roughly elliptical spots. Maxillary and mandibular barbels pale brown, gradually fading in colour distally. Anal fin with hyaline ventral margin. All other fins hyaline, with small dark-brown spots present in some specimens.

\section{Distribution}

Known from the Mekong, Chao Phraya and Pasak River drainages in IndoChina (Fig. 2).

\section{Biology}

Ompok urbaini is found most frequently in large slow-flowing rivers and lakes. It feeds on fishes and crustaceans (Rainboth, 1996; Lim et al., 1999), and migrates into inundated forest during periods of high water, where it can be found around submerged woody vegetation (Rainboth, 1996).

\section{DISCUSSION}

As previously mentioned, the name Ompok hypophthalmus has been used for three distinct species that occur allopatrically: O. hypophthalmus s. str. from Java and southern Borneo, O. rhadinurus from Sumatra, Borneo and the Malay Peninsula, and O. urbaini from Indo-China (mainland South-East Asia).

Ompok hypophthalmus differs from both O. rhadinurus and O. urbaini in having a narrower head (10.0-10.7\% $L_{\mathrm{S}}$ v. 11.4-13.6). Ompok hypophthalmus further differs from $O$. rhadinurus in having fewer vertebrae (54-55 v. 56-58) and a more slender snout (Fig. 5). Ompok rhadinurus differs from O. hypophthalmus and $O$. urbaini in having a more slender caudal peduncle (3.7-4.3\% $\left.L_{\mathrm{S}} v \cdot 4 \cdot 3-5 \cdot 9\right)$. Ompok urbaini can be distinguished from $O$. hypophthalmus and $O$. rhadinurus in having fewer vertebrae (47-52 v. 54-58) and anal-fin rays (66-71 v. 74-85). The morphometric and meristic differences between the three species are summarized in Table I.

All three species are diagnosed by each of the cartilaginous plates supporting the mandibular barbels having two posterior processes [Bornbusch (1995) had examined all three species in his study] and interestingly, the historical biogeography of this clade follows very closely that of the major drowned river systems of the Sunda shelf (which were exposed during the last glacial maxima 17000 years b.p.; Voris, 2000). The present distributions of the three species, as mapped out in current reconstructions of the ancient river systems of the Sunda shelf, are: O. hypophthalmus (East Sunda River system), O. rhadinurus (North 
(a)

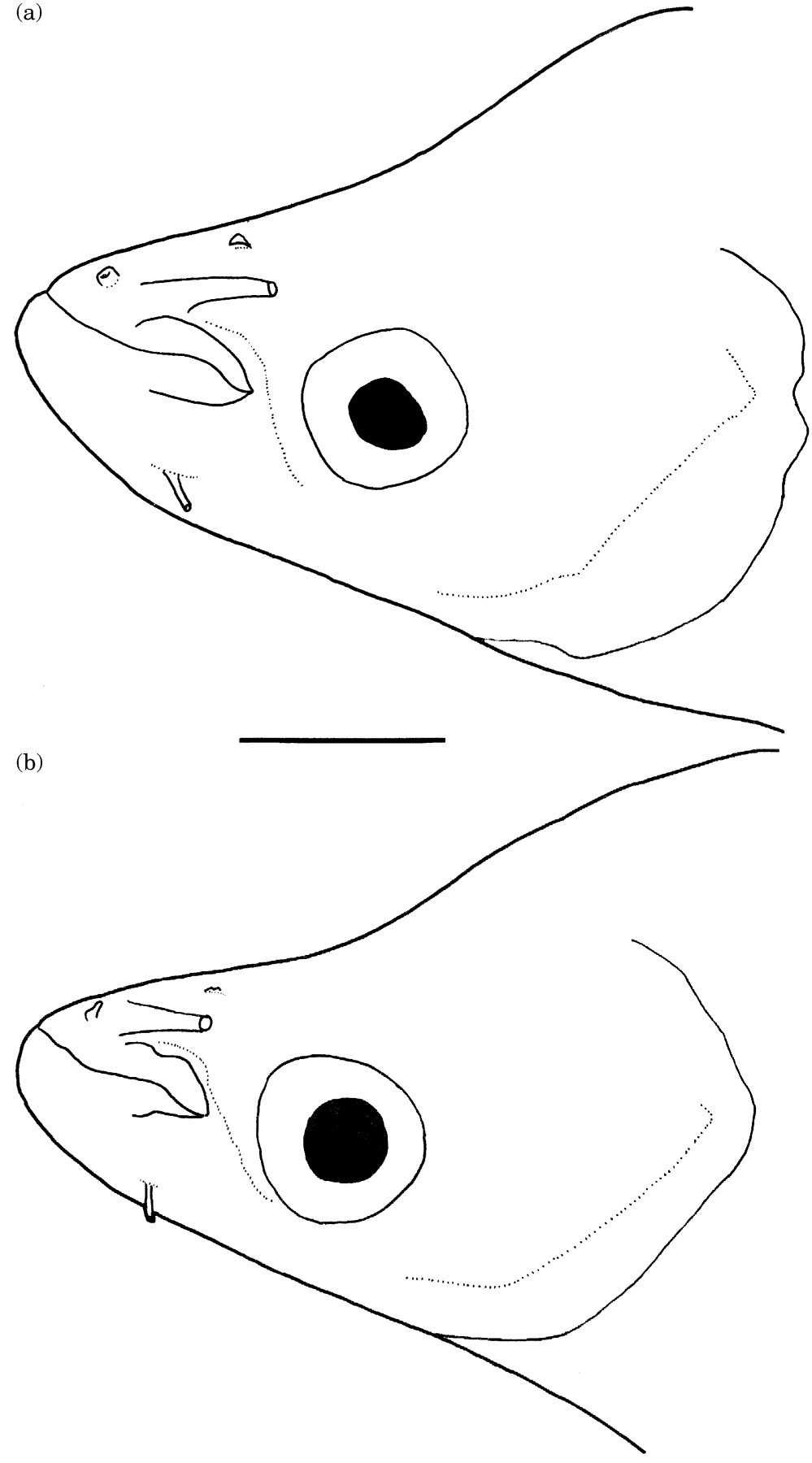

FIG. 5. Lateral views of heads of (a) Ompok hypophthalmus, ZRC 40036, 175.3 $\mathrm{mm} L_{\mathrm{S}}$ and (b) O. rhadinurus, ZRC 14897, holotype, $190.8 \mathrm{~mm} L_{\mathrm{S}}$. Scale bar represents $10 \mathrm{~mm}$. 
TABLEI. Diagnostic morphometric and meristic characters of Ompok hypophthalmus, $O$. rhadinurus and $O$. urbaini to be used in combination

\begin{tabular}{lccc}
\hline & $\begin{array}{c}\text { O. hypophthalmus } \\
(n=7)\end{array}$ & $\begin{array}{c}\text { O. rhadinurus } \\
(n=16)\end{array}$ & $\begin{array}{c}\text { O. urbaini } \\
(n=16)\end{array}$ \\
\hline Head width $\left(\% L_{\mathrm{S}}\right)$ & $10 \cdot 0-10 \cdot 7$ & $11 \cdot 4-13 \cdot 3$ & $11 \cdot 7-13 \cdot 6$ \\
Depth of caudal peduncle $\left(\% L_{\mathrm{S}}\right)$ & $4 \cdot 3-5 \cdot 1$ & $3 \cdot 7-4 \cdot 3$ & $5 \cdot 2-5 \cdot 9$ \\
Anal-fin rays & $74-80$ & $76-85$ & $65-71$ \\
Vertebrae & $54-55$ & $56-58$ & $47-52$ \\
\hline
\end{tabular}

Sunda and Siam River systems) and O. urbaini (Mekong and Siam River systems).

The occurrence of $O$. hypophthalmus in the rivers that comprised the East Sunda River (Barito River in southern Borneo and the rivers in Java) is the most interesting, since it is one of the few examples that corroborate the reconstruction of the East Sunda River. It also suggests that the freshwater fish fauna of Java is more unique than previously thought, a suggestion that is supported by increasing evidence that freshwater fishes previously thought to be conspecific throughout the Sunda shelf have been shown to consist of distinct Javanese and Sundaic (Sumatra + Borneo + Malay Peninsula) species $(\mathrm{Ng}, 2002)$.

I thank D. Nelson (UMMZ) and K. Lim (ZRC) for allowing me to examine material under their care, and to W. Rainboth for permission to use the map in Fig. 2. I am also grateful to $\mathrm{M}$. Kottelat (CMK) for critically reviewing the manuscript, providing material and assistance in checking the type material of $O$. urbaini, and to L. Parenti for critically reviewing the manuscript. This study was supported by the Rackham School of Graduate Studies of the University of Michigan.

\section{References}

Bleeker, P. (1846a). Overzicht der Siluroiden welke te Batavia voorkommen. Natuur-en Geneeskundig Archief voor Nederlandsch Indië3, 135-184. [Reprinted as Siluroideorum bataviensium conspectus diagnosticus. Verhandelingen Van Het Bataviaasch Genootschap Van Kunsten En Wetenschappen 21, 1-60.]

Bleeker, P. (1846b). Siluroideorum bataviensium species nuperrime detectae. Natuur- En Geneeskundig Archief voor Nederlandsch Indië 3, 284-293.

Bleeker, P. (1851a). Vierde bijdrage tot de kennis der ichthyologische fauna van Borneo, met beschrijving van eenige nieuwe soorten van zoetwatervisschen. Natuurkundig Tijdschrift voor Nederlandsch Indië 2, 193-208.

Bleeker, P. (1851b). Vijfde bijdrage tot de kennis der ichthyologische fauna van Borneo, met beschrijving van eenige nieuwe soorten van zoetwatervisschen. Natuurkundig Tijdschrift voor Nederlandsch Indië 2, 415-442.

Bleeker, P. (1852). Zesde bijdrage tot de kennis der ichthyologische fauna van Borneo. Visschen van Pamangkat, Bandjermassing, Praboekarta en Sampit. Natuurkundig Tijdschrift voor Nederlandsch Indië 3, 407-442.

Bleeker, P. (1853). Zevende bijdrage tot de kennis der ichthyologische fauna van Borneo. Zoetwatervisschen van Sambas, Pontianak en Pangaron. Natuurkundig Tijdschrift voor Nederlandsch Indië 5, 427-462.

Bleeker, P. (1854). Overzicht der ichthyologische fauna van Sumatra, met beschrijving van eenige nieuwe soorten. Natuurkundig Tijdschrift voor Nederlandsch Indië 7, 49-108. 
Bleeker, P. (1855a). Achtste bijdrage tot de kennis der ichthyologische fauna van Borneo. Zoetwatervisschen van Bandjermasin. Natuurkundig Tijdschrift voor Nederlandsch Indië 8, 151-168.

Bleeker, P. (1855b). Verslag van eenige verzamelingen van visschen Oost-Java. Natuurkundig Tijdschrift voor Nederlandsch Indië 9, 391-414.

Bleeker, P. (1857). Tiende bijdrage tot de kennis der ichthyologische fauna van Borneo. Visschen van de rivieren Barito, Kahajan en Kapoeas. Acta Societatia Scientiarum Indo-Neèrlandicae 2, 1-21.

Bleeker, P. (1858). De visschen van den Indischen Archipel. Beschreven en toegelicht. Siluri. Acta Societatis Scientiarum Indo-Neèrlandicae 4, i-xii+1-370. [Reprinted as Ichthyologiae Archipelagi Indici Prodromus, Vol 1. Siluri. Batavia.]

Bleeker, P. (1858-59). Vischsoorten van Palembang, verzameld door, E. A. Lange en F. J. P. Storm van's.-Gravenzande. Natuurkundig Tijdschrift voor Nederlandsch Indië 16, 263-266.

Bleeker, P. (1860a). Dertiende bijdrage tot de kennis der vischfauna van Borneo. Acta Societatia Scientiarum Indo-Neèrlandicae 8, 1-64.

Bleeker, P. (1860b). Achtste bijdrage tot de kennis der vischfauna van Sumatra. Visschen van Benkoelen, Priaman, Tandjong, Palembang en Djambi. Acta Societatia Scientiarum Indo-Neèrlandicae 8, 1-88.

Bleeker, P. (1862). Atlas Ichthyologique des Indes Orientales Néêrlandaises. Tome 2. Amsterdam: Frederic Muller.

Bornbusch, A. H. (1991). Redescription and reclassification of the silurid catfish Apodoglanis furnessi Fowler (Siluriformes: Siluridae), with diagnoses of three intrafamilial silurid subgroups. Copeia 1991, 1070-1084.

Bornbusch, A. H. (1995). Phylogenetic relationships within the Eurasian catfish family Siluridae (Pisces: Siluriformes), with comments on generic validities and biogeography. Zoological Journal of the Linnean Society 115, 1-46. doi: 10.1006/ zjls. 1995.0032 .

Chaux, J. \& Fang, P. W. (1949). Catalogue des Siluroidei d'Indochine de la collection $\mathrm{du}$ Laboratoire des Pêches Coloniales au Muséum, avec la description de six espèces nouvelles. Bulletin du Muséum National d'Histoire Naturelle, 2e série 21, 194-201.

Chevey, P. \& le Poulain, F. (1940). La pêche dans les eaux douces du Cambodge. Traveaux de l'Institut Océanographique de l'Indochine 5, 1-193.

Duncker, G. (1904). Die fische der Malayischen Halbinsel. Mittheilungen aus dem Naturhistorischen Museum Hamburg 21, 133-207.

Durand, J. (1940). Notes sur quelques poissons d'espèces nouvelles ou peu connues des eaux douces cambodgiennes. Notes Institut Océanographique de l'Indochine 36, 1-41.

Eschmeyer, W. N. (1998). The Catalog of Fishes. San Francisco, CA: California Academy of Sciences.

Günther, A. (1864). Catalogue of Fishes in the British Museum, Vol. 5. London: Trustees of the British Museum.

Haig, J. (1952). Studies on the classification of the catfishes of the Oriental and Palaearctic family Siluridae. Records of the Indian Museum 48, 59-116.

Hardenberg, J. D. F. (1936). On a collection of fishes from the estuary and the lower and middle course of the River Kapuas (W. Borneo). Treubia 15, 225-254.

Hương, T. T. T. \& Khoa, T. T. (1993). Định loại cá nước ngọt vùng dồng bằng sông Cửu Long. Cần Tho: Khoa Thủy Sản, Trường đại Học Cần Thơ (in Vietnamese).

Imaki, A., Kawamoto, A. \& Suzuki, A. (1981). Results of an ichthyological survey in the Kapuas river, west Kalimantan, Indonesia. Research Institute of Evolutionary Biology Science Reports 1, 33-54.

Kavanantkul, K., Vidthayanon, C., Termvichkorn, A. \& Sirikul, C. (2000). Fishes of the Bueng Borapet Swamp (Lower Chao Phraya Basin). Bangkok: Aquatic Natural Resources Museum, Department of Fisheries (in Thai).

Khan, M. S., Lee, P. K. Y., Cramphorn, J. \& Zakaria-Ismail, M. (1996). Freshwater Fishes of the Pahang River Basin, Malaysia. Wetlands International-Asia Pacific Publication No. 112. Kuala Lumpur: Wetlands International-Asia Pacific. 
Kottelat, M. (1985). Fresh-water fishes of Kampuchea - A provisory annotated checklist. Hydrobiologia 121, 249-279.

Kottelat, M. (2001). Fishes of Laos. Colombo: Wildlife Heritage Trust.

Kottelat, M., Ng, P. K. L. \& Lim, K. K. P. (1992). Recent collections of freshwater fish from Terengganu, Peninsular Malaysia. Malayan Naturalist 46, 7-12.

Kottelat, M., Whitten, A. J., Kartikasari, S. N. \& Wirjoatmodjo, S. (1993). Freshwater Fishes of Western Indonesia and Sulawesi. Hong Kong: Periplus Editions.

Kuronuma, K. (1961). A Check List of the Fishes of Vietnam. Saigon: Division of Agriculture and Natural Resources United States Operations Mission to Vietnam.

Lim, K. K. P., Ng, P. K. L., Kottelat, M. \& Zakaria-Ismail, M. (1993). A preliminary working wist of native freshwater fishes of peninsular Malaysia. AWB Publication No. 94. Kuala Lumpur: Asian Wetlands Bureau.

Lim, P., Lek, S., Touch, S. T., Mao, S.-O. \& Chhouk, B. (1999). Diversity and spatial distribution of freshwater fish in Great Lake and Tonle Sap river (Cambodia, Southeast Asia). Aquatic Living Resources 12, 379-386.

Mai, D. Y. \& Nguyen, V. T. (1988). Species composition and distribution of the freshwater fish fauna of southern Vietnam. Hydrobiologia 160, 45-51.

Mai, Đ. Y., Nguyễn, V. T., Nguyễn, V. T., Lê, H. Y. \& Hứa, B. L. (1992). Định loại các loài cá nước ngọt Nam Bộ. Hà Nội: Nhà Xuât Bản Khoa Học Và Kỹ Thuật (in Vietnamese).

Mizuno, N. \& Furtado, J. I. (1982). Ecological notes on fishes. In Tasek Bera: the Ecology of a Freshwater Swamp (Furtado, J. I. \& Mori, S., eds), pp. 321-354. The Hague: Junk.

Mohsin, A. K. M. \& Ambak, A. (1982). Freshwater siluroid fishes of Selangor. Malayan Nature Journal 36, 99-112.

Mohsin, A. K. M. \& Ambak, A. (1983). Freshwater Fishes of Peninsular Malaysia. Malaysia: Penerbit Universiti Pertanian Malaysia.

Mohsin, A. K. M., Ang, K. J. \& Hat, H. (1977). A list of freshwater fishes of Selangor. Malaysian Applied Biology 6, 75-78.

$\mathrm{Ng}, \mathrm{H}$. H. (2002). The identity of Mystus nigriceps (Valenciennes in Cuvier \& Valenciennes, 1840), with the description of a new bagrid catfish (Teleostei: Siluriformes) from Southeast Asia. Raffles Bulletin of Zoology 50, 161-168.

Ng, H. H. \& Tan, H. H. (1999). The fishes of the Endau drainage, Peninsular Malaysia with descriptions of two new species of catfishes (Teleostei: Akysidae, Bagridae). Zoological Studies 38, 350-366.

Ng, P. K. L., Tay, J. B., Lim, K. K. P. \& Yang, C. M. (1992). The conservation of the fish and other aquatic fauna of the North Selangor peat swamp forest and adjacent areas. AWB Publication No. 81. Kuala Lumpur: Asian Wetlands Bureau.

Orsi, J. J. (1974). A check list of the marine and freshwater fishes of Vietnam. Publications of the Seto Marine Biological Laboratory 21, 153-177.

Rainboth, W. J. (1996). Fishes of the Cambodian Mekong. FAO Species Identification Field Guide for Fishery Purposes. Rome: FAO.

Roberts, T. R. (1989). The freshwater fishes of western Borneo (Kalimantan Barat, Indonesia). Memoirs of the California Academy of Sciences 14, i-xii+1-210.

Roberts, T. R. (1993a). The freshwater fishes of Java, as observed by Kuhl and van Hasselt in 1820-23. Zoologische Verhandelingen 285, 1-94.

Roberts, T. R. (1993b). Artisanal fisheries and fish ecology below the great waterfalls of the Mekong river in southern Laos. Natural History Bulletin of the Siam Society 41, 31-62.

Roberts, T. R. \& Warren, T. J. (1994). Observations on fishes and fisheries in southern Laos and northeastern Cambodia, October 1993-February 1994. Natural History Bulletin of the Siam Society 42, 87-115.

Serov, D. V. (1994a). The analysis and distribution of the freshwater ichthyofauna in waters of South Vietnam. In Gidrobionty iuzhnogo V'etnama: sbornik nauchnykh trudov (Pavlov, D. S. \& Sbikin, I. U. N., eds), pp. 17-30. Moscow: Nauka (in Russian with English abstract).

Serov, D. V. (1994b). Polevoi opredelitel' presnovodnykh ryb iuzhnogo V'etnama. [Field Identification Guide to the Freshwater Fishes of South Vietnam]. Moscow: Nauka (in Russian). 
Smith, H. M. (1933). Contributions to the ichthyology of Siam. II. New species of loaches of the genus Nemacheilus. III. A new genus and new species of cyprinoid fishes. IV. A new goby of the genus Vaimosa. V. A new genus and new species of glyptosternoid catfishes. VI. Fishes not previously recorded from Siam. Journal of the Siam Society, Natural History Supplement 9, 53-87.

Smith, H. M. (1945). The freshwater fishes of Siam or Thailand. Bulletin of the U.S. National Museum 188, 1-622.

Suvatti, N. C. (1936). Index to Fishes of Siam. Bangkok: Bureau of Fisheries.

Suvatti, N. C. (1950). The Fauna of Thailand. Bangkok: Department of Fisheries.

Suvatti, N. C. (1981). Fishes of Thailand. Thailand: The Royal Institute (in Thai).

Taki, Y. (1978). An analytical study of the fish fauna of the Mekong basin as a biological production system in nature. Research Institute of Evolutionary Biology Special Publications 1 (Tokyo).

Tan, H. H. \& Ng, H. H. (2000). The catfishes (Teleostei: Siluriformes) of central Sumatra. Journal of Natural History 34, 267-303.

Vidthayanon, C., Karnasuta, J. \& Nabhitabhata, J. (1998). Diversity of Freshwater Fishes in Thailand. Bangkok: Office of Environmental Policy and Planning.

Volz, W. (1904). Fische von Sumatra gesammelt von Herrn G. Schneider. Revue Suisse de Zoologie 12, 451-493.

Volz, W. (1907). Catalogue of the fishes of Sumatra. Natuurkundig Tijdschrift voor Nederlandsch Indië $\mathbf{6 6}, 35-250$.

Voris, H. K. (2000). Maps of the Pleistocene sea levels in Southeast Asia: shorelines, river systems and time durations. Journal of Biogeography 27, 1153-1167.

Weber, M. \& de Beaufort, L. F. (1912). Fische. In Durch Zentral-Sumatra, Band II (Maass, A., ed.), pp. 522-541. Leipzig: W. Süsserott.

Weber, M. \& de Beaufort, L. F. (1913). The Fishes of the Indo-Australian Archipelago, Vol. 2. Leiden: E. J. Brill. 